\title{
Degree-day glacier mass-balance modelling with applications to glaciers in Iceland, Norway and Greenland
}

\author{
Tómas Jóhannesson, Oddur Sigurdsson, \\ Orkustofnum (National Energy Authority), IS-108 Reykjavik, Iceland \\ Tron Laumann and Michael Kennett \\ NVE (Norwegian Water Resources and Energy Administration), P.O. Box 5091, Maj., N-0301 Oslo, Nonway
}

\begin{abstract}
A degree-day glacier mass-balance model is applied to three glaciers in Iceland, Norway and Greenland for which detailed mass-balance measurements are available over a period of several years. Model results are in good agreement with measured variations in the mass balance with elevation over the time periods considered for each glacier. In addition, the model explains $60-80 \%$ of the year-toyear variance in the elevation-averaged summer season mass-balance measurements on the glaciers, using a single parameter set for each glacier.

The increase in ablation on the glaciers due to a warming of $2^{\circ} \mathrm{C}$ is predicted to range from about $1 \mathrm{~m}$ w.e. year ${ }^{-1}$ at the highest elevations to about $2.5 \mathrm{~m}$ w.e. year ${ }^{1}$ at the lowest elevations. Predicted changes in the winter balance measured between fixed dates) are relatively small, except at the lowest elevations on the Icelandic and Norwegian glaciers where the winter balance is significantly reduced. Equilibrium-line altitudes are raised by $200-300 \mathrm{~m}$ on the Icelandic and Norwegian glaciers. Except at the highest elevations, the winter balance of the Icelandic and Norwegian glaciers is predicted to decrease even if the warming is accompanied by a $10 \%$ increase in the precipitation.

No firm evidence of a climate-related variation in the degree-day factors or in the temperature lapse rate on the same glacier could be found. The model, furthermore, reproduces large variations in the mass balance with elevation and from year to year on each glacier using the same parameter set. We assume, therefore, that these parameters will not change significantly for the climate scenarios considered here.
\end{abstract}

\section{INTRODUCTION}

It is estimated that the mean surface air temperature of the Earth will rise at a rate in the order of $0.3^{\circ} \mathrm{C}$ per decade during the next decades due to increasing concentrations of $\mathrm{CO}_{2}$ and other trace gases in the atmosphere (Houghton and others, 1990, 1992). This rate of warming will have pronounced effects on glaciers and ice caps and lead to major run-off changes in glacierized areas. The Nordic research project "Climate change and energy production" (Sxlthun, 1992) was started in 1991 with the aim of estimating the hydrological effects of global warming in the Nordic countries with special emphasis on the possible consequences for the operation and planning of hydroelectric power plants.

As a part of this project, a degree-day glacier massbalance model for temperate glaciers has been developed in order to estimate the effects of global warming on glacier mass balance and run-off from glacierized areas. This model has been tested on the glaciers Sátujökull (part of Hofsjökull), central Iceland, Nigardsbreen (part of Jostedalsbreen), southern Norway, and Qamanârssûp sermia (outlet glacier from the Greenland ice sheet), West Greenland. In this paper, we describe the application of the mass-balance model to these glaciers and compute the predicted effect of climatic warming on the mass balance and on the run-off from these glaciers. The stability of the model parameters over the period of measurements is analyzed in order to assess whether these parameters are likely to change as a consequence of the climate changes which are considered.

Mass-balance data from glaciers and ice sheets contain implicit information about the dependence of glacier mass balance on climate. The measured mass balance varies with elevation and from year to year, mainly as a consequence of variations in temperature and precipitation. It should, therefore, be possible to use measured variations in the mass balance together with meteorological data to parameterize the relation between glacier mass balance and climate using a suitable glacier massbalance model. The mass-balance model may then be used to estimate likely glacier mass-balance changes resulting from hypothetical climatic changes.

The mass-balance measurements from the three glaciers come from different climate regimes and should therefore be a good test of the applicability of a degreeday glacier mass-balance model over a wide range of conditions. Sátujökull is an outlet glacier from an ice cap 
in the middle of the Icelandic highland; Nigardsbreen is a narrow valley glacier with a wide elevation range; and the measurements from Qamanârssûp sermia come from the ablation area of the Greenland ice sheet. The measurements from Nigardsbreen cover 24 years, which can be divided into sub-sets with significantly different climate conditions, and are therefore especially suitable for an analysis of the stability of model parameters. Detailed energy-balance and degree-day glacier massbalance modelling has previously been applied to mass balance and meteorological data from Qamanârssûp sermia, and our results can therefore be compared to previous results from this glacier (cf. Braithwaite and Olesen, 1989, 1990a, 1993).

The mass-balance modelling presented here is a continuation of the modelling described by Laumann and Reeh (1993) which applied a similar degree-day glacier mass-balance model to three glaciers in Norway. The model used here has been improved to accommodate daily and monthly input data instead of yearly data, and the calibration of the model is based on yearly massbalance measurements rather than long-term massbalance averages. We place special emphasis on the stability of the model parameters by analyzing how well the model explains yearly mass-balance variations and we test the applicability of the degree-day model by applying it to three glaciers in very different climate regimes.

\section{MODEL DESGRIPTION}

The glacier mass-balance model, which is termed MBT (an acronym for Mass Balance of Temperate glaciers), is based on existing degree-day hydrological and glacier massbalance models which have been used extensively in the Nordic countries (Jóhannesson and Laumann, 1993): the HBV model (Bergström, 1976; Sælthun, 1990), the NAM2 model (Gottlieb, 1980; Holm and Einarsson, 1992), the MB1 model (Braithwaite, 1984) and a glacier massbalance model described by Reeh (1991) and Laumann and Reeh (1993).

A degree-day model was chosen for this analysis in preference to an energy-balance model for the following reasons:

1. The formulation of the mass balance in terms of temperature and precipitation is advantageous for simulations of the response of glacier mass balance to climatic changes, since climate scenarios are typically given in terms of temperature and precipitation changes. Scenarios for future changes in cloudiness, cloud height, wind speed, relative humidity and other variables which are often required in energy-balance models (Braithwaite and Olesen, 1990b; Oerlemans, 1992) are in general not available.

2. The use of energy-balance models to compute glacier mass balance over whole ice caps or glaciers raises difficult questions about the variation of input data and model parameters over the area covered by the ice cap or glacier (Braithwaite, 1992). Except for temperature, the input data are in general not readily extrapolated away from measurement locations. Similar problems are, of course, also encountered for degree-day models but they are not as serious as for energy-balance models.

3. Energy-balance models do not seem to perform better than degree-day models in practical hydrological applications when modelling daily run-off on catchment scale (Bergström and others, 1992).

4. Degree-day coefficients show a high degree of stability with time and across a wide range of different climatic regimes Braithwaite and Olesen, 1984, 1989; Bergström and others, 1992; Braithwaite, 1992).

5. A degree-day glacier mass-balance model can benefit from the considerable practical experience with similar glacier (MB1) and hydrological models (HBV, NAM2) which has been built up in Denmark, Greenland, Iceland, Norway and Sweden.

6. Experience from a degree-day mass-balance model can be used to improve existing hydrological models in partly glacierized catchments (Einarsson and Jóhannesson, 1994).

The mass-balance model determines the precipitation, snow accumulation, melting of snow and ice, and refreezing as a function of altitude based on observed temperature and precipitation at a meteorological station. The total ablation, mass balance and run-off can then be computed. Precipitation and temperature on the glacier are computed assuming a linear precipitation variation with altitude and a constant temperature lapse rate with altitude.

The model computations are based on daily, monthly or yearly precipitation values. The temperature is specified as a series of daily or monthly mean values or as a sinusoidal function with a period of 1 year according to the following equation

$$
T_{\mathrm{d}}(t)=T_{\mathrm{a}}+T_{\mathrm{co}} \cos (2 \pi t / A)+T_{\mathrm{si}} \sin (2 \pi t / A)
$$

where $t$ is time since the beginning of the mass-balance year (in days), $A$ is the length of the year (in days), $T_{\mathrm{a}}$ is the average temperature of the year, and $T_{\mathrm{co}}$ and $T_{\mathrm{si}}$ are coefficients. A statistical approach is used in the determination of the number of positive degree-days and snow accumulation (see below) when the temperature is given as monthly mean values or as a sinusoidal function. Temperature deviations from the monthly mean or from the sinusoidal function are assumed to be normally distributed with a standard deviation $\sigma$ (cf. Braithwaite, 1984; Reeh, 1991). Precipitation is assumed to be evenly distributed in time in the statistical computation of snow accumulation from monthly and yearly input values.

Precipitation on the glacier is assumed to fall as snow, if the temperature at the altitude in question is below a specified threshold. This threshold is typically about $1^{\circ} \mathrm{C}$. A wind correction with separate correction factors for rain and snow may be applied to the precipitation data before they are used in the mass-balance computations. When 
the temperature is specified as monthly mean values, the fraction $f$ of the precipitation that falls as snow in a given month is given by

$$
f=\frac{1}{\sigma \sqrt{2 \pi}} \int_{-\infty}^{T_{\mathrm{s}}} \mathrm{e}^{-\left(T-T_{\mathrm{m}}{ }^{2}\right) /\left(2 \sigma^{2}\right)} \mathrm{d} T
$$

where $T$ is temperature, $T_{\mathrm{s}}$ is the rain/snow threshold temperature and $T_{\mathrm{m}}$ is the monthly mean temperature. When the temperature is specified as a sinusoidal function, the fraction of the precipitation that falls as snow in a given period from day $D_{1}$ to day $D_{2}$ is given by

$$
f=\frac{1}{D} \int_{D_{1}-1}^{D_{2}} \frac{1}{\sigma \sqrt{2 \pi}} \int_{-\infty}^{T_{*}} \mathrm{e}^{-\left(T-T_{\mathrm{d}}(t)\right)^{2} /\left(2 \sigma^{2}\right)} \mathrm{d} T \mathrm{~d} t
$$

where $D=D_{2}-D_{1}+1$ is the period length in days and $T_{\mathrm{d}}(t)$ is given by Equation (1). The fraction $f$ determined from Equations (2) and (3) is equal to the fraction of the period with $T<T_{\mathrm{s}}$.

Melting of snow and ice is computed from the number of positive degree-days (PDD), using different degree-day factors (amount of melting per PDD) for snow and ice (cf. Braithwaite and Olesen, 1989; Reeh, 1991). When the temperature is specified as monthly mean values, PDD is given by

$$
\mathrm{PDD}=\frac{365 / 12}{\sigma \sqrt{2 \pi}} \int_{0}^{\infty} T \mathrm{e}^{-\left(T-T_{\mathrm{m}}\right)^{2} /\left(2 \sigma^{2}\right)} \mathrm{d} T
$$

where the number of days in a year has been distributed evenly among the months for simplicity. When the temperature is specified as a sinusoidal function, PDD is given by

$$
\mathrm{PDD}=\int_{D_{1}-1}^{D_{2}} \cdot \frac{1}{\sigma \sqrt{2 \pi}} \int_{0}^{\infty} T \mathrm{e}^{-\left(T-T_{\mathrm{d}}(t)\right)^{2} /\left(2 \sigma^{2}\right)} \mathrm{d} T \mathrm{~d} t .
$$

When the snow thickness becomes less than a specified threshold, the degree-day factor is found as a weighted average of the degree-day factors for snow and ice. The reason for this is that the snow-line is not a sharp welldefined line at a certain altitude. Rather, it represents a transition from a surface of clean ice to a surface completely covered by snow, where patches of clean ice and snow will be mixed.

The model computes the amount of stored meltwater or rain (which may be frozen) by assuming that the storage is a certain fraction of the amount of remaining snow. This fraction is specified as a model parameter and is typically between $5 \%$ and $10 \%$. This storage leads to a delay in the onset of glacier run-off with respect to the start of melting on the glacier.

The ablation is defined as the negative of the melting (of both snow and ice) plus the refrozen and/or stored liquid water. The mass balance is the sum of the accumulation and the ablation. The run-off from each elevation on the glacier is given as the precipitation minus the mass balance.

The model computes mass balance over a specified time interval which is usually whole or part of a massbalance year. A more detailed description of the model has been given by Jóhannesson and others (1993).

\section{MASS-BALANCE MEASUREMENTS AND MODEL CALIBRATION}

The mass-balance model calculates total accumulation, total ablation and therefore the mass balance at specified elevations on the glacier surface between given dates. These quantities are not always directly comparable to traditional glacier mass-balance measurements. In order to calibrate the model, using measured mass balance, it is important to take account of the measurement dates and to consider the exact meaning of the various terms in published mass-balance data (cf. Ostrem and Brugman, 1991).

Until 1975, mass balance on Nigardsbreen was measured frequently during the summer by field assistants, in order to obtain the balance at the end of the stratigraphic balance year, both in the accumulation area and on the glacier tongue. The published figures are therefore derived from measurements made on different dates and at different locations on the glacier. In later years, the same date was used over the whole glacier, although new snow lying on the summer surface was not included in the summer balance. In addition, winter balance in the ablation area was usually measured by probing rather than by stake measurements, such that melting of ice during the previous autumn (after the summer-balance measurements) was counted as part of the summer balance instead of the winter balance. Thus, comparison of modelled and measured mass balance for Nigardsbreen is complicated.

The mass balance of Hofsjökull and Qamanârssûp sermia is measured between known calendar dates and it is therefore straightforward to compare the model results with the measured summer, winter or yearly balance.

The purpose of model calibration is to find the set of parameters which leads to the smallest prediction error when the mass balance found by the model is compared with the actual mass-balance measurements. When measurements of both winter and summer balance are used, the model is run in two steps, first from the autumn to the spring and then from the spring to the autumn, in order to compute winter- and summer-balance values which are directly comparable with the measurements. For Nigardsbreen, one should ideally use different dates for different years and different altitudes and adjust the computed balance for late summer snowfall and melting of ice during the autumn after the summer-balance measurements, but there are practical difficulties which prevent us from making this correction (see below).

The model uses a total of 13 parameters when the mass balance is computed from daily temperature and precipitation data (cf. Jóhannesson and others, 1993). Some of the parameters are known i.e. the altitudes of the meteorological stations). Others are given fixed values which are not changed in the calibration. These are the snow/rain threshold temperature, the rain and snow correction factors, the precipitation correction and the starting elevation for the precipitation gradient, the threshold snow thickness for blending of the degree-day factors for snow and ice, and the refreezing ratio. This leaves four parameters, i.e. the degree-day factors for snow and ice, and the temperature and precipitation gradients, which have to be determined by calibration. 
The snow/rain threshold has a similar value to that used in hydrological models in the Nordic countries. The value of the refreezing ratio is chosen on the basis of unpublished measurements of the liquid-water content and temperature of snow in Norway. It is similar to the hydrologically determined ratio which is used in the HBV model in Sweden and Norway. The values of the fixed model parameters for the three glacers are given in the tables in the following section.

The model parameters which are considered in the calibration are determined by running the model for all years within the calibration period, and finding the parameter values which minimize the sum of squares of the residuals, i.e. the differences between the model output and the measurements for every year. The minimization is carried out iteratively using a non-linear least-squares routine (nls) which is a part of the statistical package S Chambers and Hastie, 1992). This calibration procedure is somewhat different from the method used by Laumann and Reeh (1993) for Nigardsbreen. The latter is based on a comparison of the average computed accumulation and ablation with average measured winter and summer balances. However, in the method described here, the mass balance which corresponds to the massbalance measurements (winter, summer or year) is computed directly. Furthermore, the year-to-year variability of the measured mass balance is explicitly considered when the best model parameters are determined.

The computed summer balance is dependent on the degree-day factors and on the temperature gradient, but they are relatively insensitive to the precipitation gradient. The computed winter balance, on the other hand, is most sensitive to the value of the precipitation gradient. The degree-day factors and the temperature gradient for Nigardsbreen and Sátujökull are found by minimizing the residuals in the summer balance after a suitable value of the precipitation gradient has been found. The precipitation gradient is determined by trial and error, primarily on the basis of the winter-balance measurements. This is done in order to prevent undesirable effects from errors in the predicted winter balance on the degree-day factors and the temperature gradient. For Qamanârssûp sermia, yearly mass-balance measurements are used for simplicity and the precipitation gradient is set to zero based on scattered winter-balance measurements (personal communication from R.J. Braithwaite).

\section{RESULTS}

\section{Sátujökull, central Iceland}

Mass-balance measurements have been carried out on Sátujökull by Orkustofnun since 1988 (Sigurdsson, 1989, 1991, 1993). The model computations are based on temperature and precipitation measurements at Hveravellir $\left(64^{\circ} 52^{\prime} \mathrm{N}, 19^{\circ} 34^{\prime} \mathrm{W}\right.$; $641 \mathrm{~m}$ a.s.l., about $33 \mathrm{~km}$ from the glacier). Daily meteorological measurements at Hveravellir are available from the Icelandic Meteorological Institute from 1965. Data from the five mass-balance years 1987-88 to 1991-92 are used in the analysis below. The spring and autumn mass-balance measurements on Sátujökull are carried out between 10 and 20 May and

between 10 and 30 September each year. For simplicity, the starting points of the winter and summer seasons in the computations are put equal to 1 October and 1 May for all years.

The fixed model parameters for Sátujökull are given in Table 1.

Table 1. Fïxed model paramelers for Sátujökull

Parameler

Snow/rain threshold

Rain-correction factor

Snow-correction factor

Precipitation-correction factor

Snow thickness used in

degree-day computations

Refreezing ratio

Elevation of temperature station

Elevation of precipitation station

Starting elevation for

precipitation gradient

The rain- and snow-correction factors rko and sko are the recommended values for the meteorological station at Hveravellir (Sigurdsson, 1990). The starting elevation for the precipitation gradient computations elq, is chosen equal to the lowest elevation on the glacier. The precipitation correction pko is used to compute the precipitation at this elevation from the corrected precipitation at Hveravellir. The value of pko was chosen by comparison of precipitation data from Hveravellir and measured winter balance at the lowest elevations on the glacier.

The calibration of the degree-day factors and the temperature gradient was carried out first for each of the 5 years, individually. The parameter estimates showed considerable scatter. A special case was the estimated degree-day factor for snow for the mass-balance year 1990 91, which was $0.01 \mathrm{~m}$ w.e. ${ }^{\circ} \mathrm{C}^{-1} \mathrm{~d}^{-1}$, larger than the degree-day factor for ice, $0.007 \mathrm{~m}$ w.e. ${ }^{\circ} \mathrm{C}^{-1} \mathrm{~d}^{-1}$ and almost twice as large as the estimated degree-day factor for snow for the other years. The glacier was covered by black ash from an eruption from Mount Hekla during this year. The ash greatly increased the melting of snow, because of the reduced albedo of the snow surface. The melting of the ice, on the other hand, was not affected to the same extent, because the ash was quickly washed off the smooth ice surface. The data from the mass-balance year 1990-91 were therefore not used in the remainder of the calibration.

The precipitation gradient was determined as 55\% per $100 \mathrm{~m}$. The degree-day factors and the temperature gradient were determined by minimizing the residuals from the summer-balance measurements. The best-fit parameters are given in Table 2.

These parameter values explain $95 \%$ of the variance in the measured summer balance of Sátujökull at the individual elevations, but only $42 \%$ of the variance in the 
Table 2. Best-fit parameter values determined from the measured summer and winter balance of Sátujökull

\section{Parameler}

Name Value Unil
Degree-day factor for ice

Degree-day factor for snow

Temperature lapse rate

Precipitation/elevation gradient

Residual variance

Residual standard error ddi $0.0077 \mathrm{~m}$ w.e. ${ }^{\circ} \mathrm{C}^{-1} \mathrm{~d}^{-1}$ dds $0.0056 \mathrm{mw}^{\circ}$.e. $\mathrm{C}^{-1} \mathrm{~d}^{-1}$ grt $0.53{ }^{\circ} \mathrm{C}$ per $100 \mathrm{~m}$ grp 0.551 per $100 \mathrm{~m}$ winter-balance measurements. The estimated degree-day factor for snow is consistent with previous estimates of degree-day factors for snow in Iceland $0.0040 .010 \mathrm{~m}$ w.e. $\mathrm{C}^{-1} \mathrm{~d}^{1}$, cf. Bergström and others, 1992), and somewhat higher than in Scandinavia $0.0018-0.005 \mathrm{~m}$ w.e. ${ }^{\circ}{ }^{1} \mathrm{~d}^{-1}$, cf. Bergström and others, 1992). The estimated degree-day factor for ice is similar to values determined for glaciers in West and northeast Greenland 0.0077 and $0.0094 \mathrm{~m}$ w.e. ${ }^{\circ} \mathrm{C}^{-1} \mathrm{~d}^{1}$, cf. Braithwaite and Olesen, 1989; Boggild and others, 1994).

Figure la-e shows measured and computed mass balance for the five mass-balance years. The parameters in Tables 1 and 2 are used for all the years. Figure if shows the average of the mass balance measurements for the four mass-balance years 1987-88, 1988 89, 1989-90 and 1991-92, together with the computed mass balance using the mean yearly precipitation and a sinusoidal representation of the temperature record at Hveravellir for the same years. The standard deviation of the temperature deviations from the sinusoidal temperature approximation was chosen as $\sigma=3.32^{\circ} \mathrm{C}$, based on the standard deviation of measured temperature deviations from the sinusoidal function during the melting season (May-September). The figures show that the variation of the summer balance with elevation and between years is in general well explained (except for 1990-91). Year-toyear fluctuations in the winter balance are, on the other hand, not well explained by the model and the variation of the winter balance with elevation is not well predicted. This is probably due to the large spatial variability in precipitation. The minimum in the winter balance around $1000 \mathrm{ma}$ a.s.l. is caused by wind transport of snow which cannot be explained by the linear increase of precipitation with elevation used in the model. The parameter set of Table 2 leads to an underestimate in the summer melting for the year 1990 91 when the glacier was covered by ash. A better fit was obtained using an increased degree-day factor for snow $(\mathrm{dds}=0.009 \mathrm{~m}$ w.e. ${ }^{\circ} \mathrm{C}^{-1} \mathrm{~d}^{-1}$ ) and a higher value of the precipitation gradient $(\operatorname{grp}=90 \%$ per $100 \mathrm{~m})$ for this year and the results are shown as dashed curves in Figure ld. The average results for the 4 years $1987-88,1988-89,1989-90$ and 1991-92 (Fig. 1f) are better than for the individual years, for both the summer and the winter balance.

Figure 2a shows a scatter diagram of the measured and computed mass balance of Sátujökull for the massbalance years 1987-88, 1988-89, 1989 - 90 and 1991-92. Figure 2 a shows the variation of the mass balance with elevation and from year to year on the glacier. The

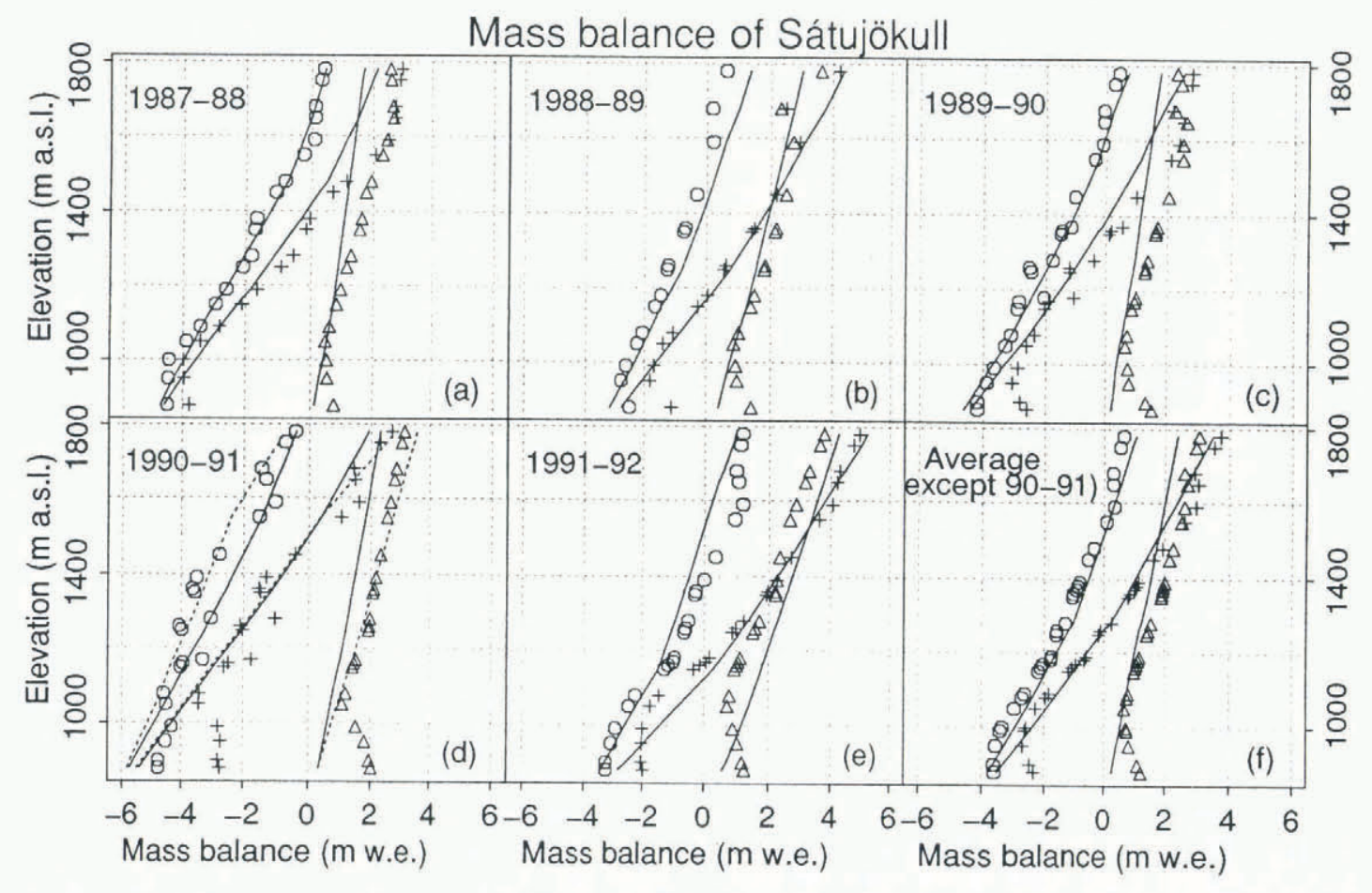

Fig. 1. Measured (symbols) and compuled (solid curves) mass balance (winter $(\triangle)$, summer $(\bigcirc)$ and year $(+))$ at Sátujökul for the mass-balance years 1987-88 to 1991 92, and for the average of the years 1987-88, 1988 89, 1989-90 and 1991-92. Model parameters are the same for all the years (cf. Tables 1 and 2). The dashed curves for 199091 are produced with a different parameter set (ddi $=0.0077 \mathrm{mw}$.e. ${ }^{\circ \mathrm{Cd}^{-}}{ }^{1}$, dds $=0.009 \mathrm{mw} . e .{ }^{\circ} \mathrm{Cd}^{1}, \mathrm{grt}=0.53^{\circ} \mathrm{C}$ per $100 \mathrm{~m}$ and grp $=90 \%$ per $100 \mathrm{~m}$ ). 

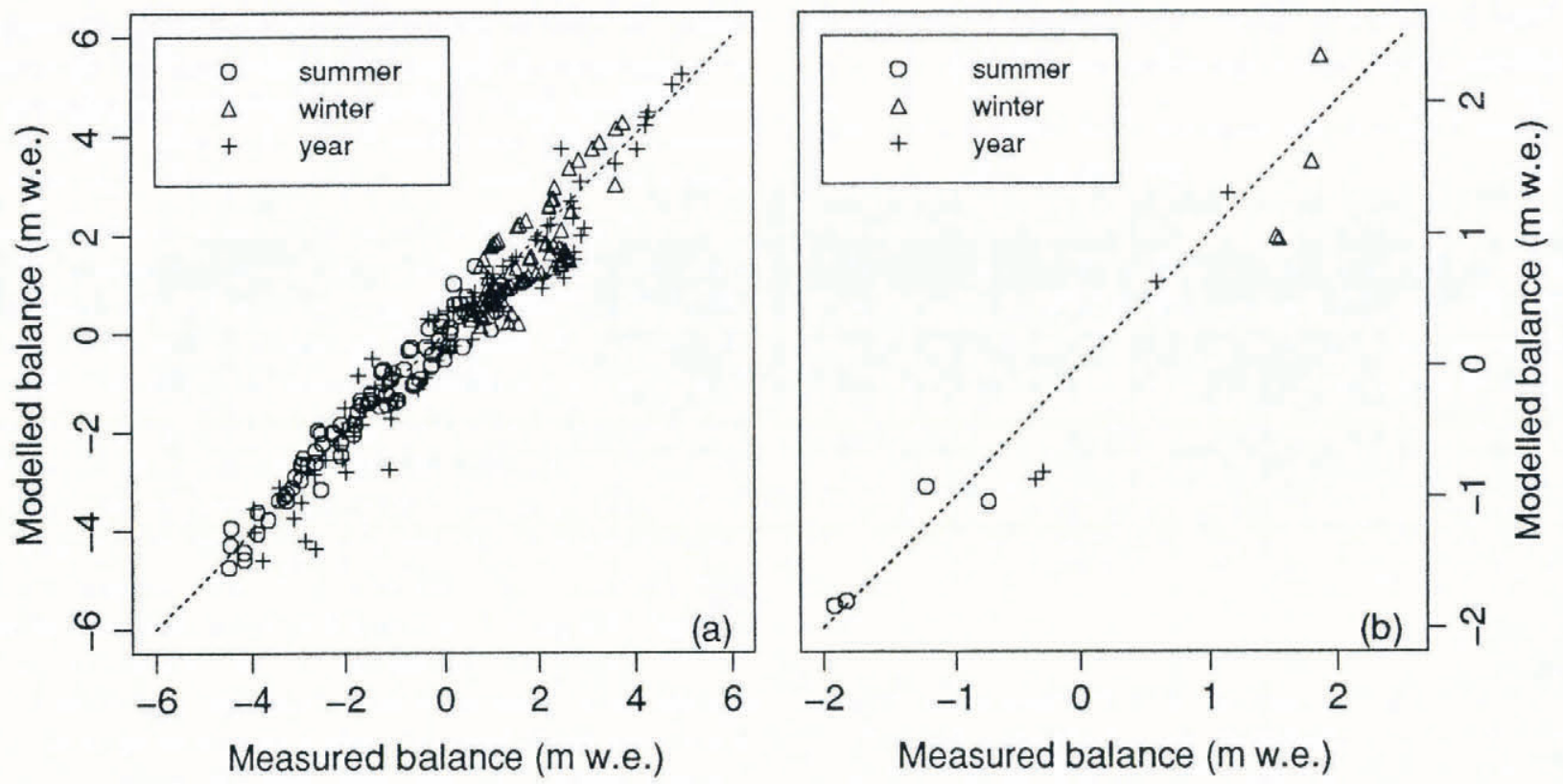

Fig. 2. Measured and computed mass balance of Sátujökull for the mass-balance years 1987-88, 1988-89, 198990 and 1991-92. (a) Winter $(\triangle)$, summer $(\bigcirc)$ and yearly $(+)$ mass balance of individual years at each elevation. (b) Elevation-averaged values for each year.

summer-balance values show a large spreading and are well predicted by the model (model explains 95\% of variance). The winter-balance values show much less spreading, although similar deviations from the diagonal, and the model performance is therefore worse (model explains $42 \%$ of variance) than for the summer balance. Figure $2 \mathrm{~b}$ shows the mass balance averaged over all elevations, in order to assess the ability of the model to explain year-to-year mass-balance variations on the basis of year-to-year temperature and precipitation fluctuations. It is seen that the summer-balance variations are rather well predicted by the model (model explains $79 \%$ of variance). Year-to-year variations in the winter balance are much smaller and are not well predicted by the model. It should be borne in mind that the above results for Sátujökull are based on measurements from only four mass-balance years.

\section{Nigardsbreen, southern Norway}

Mass-balance measurements have been carried out on Nigardsbreen by NVE since 1962 (Norges Vassdrags- og Energivork (NVE), 1964 91). The model computations are based on temperature and precipitation measurements at Bjørkehaug $\left(61^{\circ} 40^{\prime} \mathrm{N}, 07^{\circ} 18^{\prime} \mathrm{E}, 324 \mathrm{~m}\right.$ a.s.l.) about $5 \mathrm{~km}$ from the glacier. Daily meteorological measurements at Bjørkehaug are available from the Norwegian Meteorological Institute (DNMI) for all years since the mass-balance measurements were started, with the exception of parts of the mass-balance years 1981-82 and 1982-83. Data from the mass-balance years 196465 to $1980-81$ and $1983-84$ to $1989-90$ (a total of 24 years) are used in the analysis below. Previously published values from below $550 \mathrm{~m}$ a.s.l. were not used, as they are based on an extrapolation below the lowest measurements.

The mass-balance measurements were made on

different dates on different parts of the glacier in many years. Accurate information about the measurement dates is lacking in many of the mass-balance reports from NVE. It has not been possible to account for this problem with the measurement dates. We have therefore defined the starting points of the winter and summer seasons as 10 September and 15 May for all years. These dates are less than 2-3 weeks in error for most years, but can be up to 2 months in error in some years. We have experimented with different dates for the years where accurate measurement dates are available and have found that the model output is significantly improved in some cases.

The fixed-model parameters for Nigardsbreen are given in Table 3.

Scattered temperature measurements carried out on the tongue of Nigardsbreen at the same elevation as the Bjorkehaug meteorological station, give between $1^{\circ}$ and $2{ }^{\circ} \mathrm{C}$ lower temperatures than at Bjørkehaug. This is taken

Table 3. Fixed-model parameters for Nigardsbreen

Parameter Name Value Unit

Snow/rain threshold

Rain-correction factor

Snow-correction factor

Precipitation-correction factor

Snow thickness used in degree-day computations

Refreezing ratio

Elevation of temperature station

Elevation of precipitation station

Starting elevation for precipitation gradient 
into account by lowering the elevation of the temperature station in the computations by $200 \mathrm{~m}$. The rain- and snowcorrection factors rko and sko are similar to the default values in the Norwegian version of the HBV model.

The precipitation gradient was found by using the average winter balance for all 24 years and determined to be $9 \%$ per $100 \mathrm{~m}$. The degree-day factors and the temperature gradient were determined by minimizing the residuals from the summer-balance measurements. The best-fit parameters are given in Table 4 .

Table 4. Best-fit parameter values determined from the measured summer and winter balance of Nigardsbreen

\section{Parameter Name Value Unit}

$\begin{array}{llll}\text { Degree-day factor for ice } & \text { ddi } & 0.0064 \mathrm{~m} \text { w.e. }{ }^{\circ} \mathrm{C}^{-1} \mathrm{~d}^{-1} \\ \text { Degree-day factor for snow } & \text { dds } & 0.0044 \mathrm{~m} \text { w.e. }{ }^{\circ} \mathrm{C}^{-1} \mathrm{~d}^{-1} \\ \text { Temperature lapse rate } & \text { grt } & 0.58 & { }^{\circ} \mathrm{C} \text { per } 100 \mathrm{~m} \\ \text { Precipitation/elevation } & \text { grp } & 0.09 & 1 \text { per } 100 \mathrm{~m}\end{array}$
gradient
Residual variance
$\sigma_{\delta}^{2} \quad 0.39$
$\mathrm{m}^{2}$ w.e.
Residual standard error
$\sigma_{\delta} \quad 0.63$
mw.e.

These parameter values explain $94 \%$ of the variance in the measured summer balance and $67 \%$ of the variance in the winter balance at the individual elevations. The estimated degree-day factors are consistent with the results of previous studies (Norges Vassdrags- og Energivork (NVE), 1964 91; Furmyr and Tollan, 1975). The degree-day factors used in Laumann and Reeh (1993) $0.0055 \mathrm{~m}$ w.e. ${ }^{\circ} \mathrm{C}^{-1} \mathrm{~d}^{-1}$ for ice and $0.004 \mathrm{~m}$ w.e. ${ }^{\circ} \mathrm{C}^{-1} \mathrm{~d}^{-1}$ for snow) are slightly lower than found here, because they have not lowered the elevation of Bjorkehaug. The estimated temperature gradient of $0.58^{\circ} \mathrm{C}$ per $100 \mathrm{~m}$ is in good agreement with the gradient estimated from temperature measurements on the glacier tongue and at Steinmannen $\left(61^{\circ} 4 \mathrm{l}^{\prime} \mathrm{N}, 07^{\circ} 08^{\prime} \mathrm{E}, 1634 \mathrm{~m}\right.$ a.s.l.).

Figure $3 \mathrm{a}$ and $\mathrm{b}$ shows the measured and the computed mass balance for two of the 24 mass-balance years using the parameters given in Tables 3 and 4 for both years. Figure 3a shows one of the six best years (1965-66) and Figure 3b shows one of the six worst years (1980 81). Figure 3c shows the average of the massbalance measurements for all 24 mass-balance years together with the computed mass balance using the mean yearly precipitation and a sinusoidal representation of the temperature record at Bjorkehaug for the same years. The standard deviation of the temperature deviations from the sinusoidal temperature approximation was chosen to be $\sigma=3.12^{\circ} \mathrm{C}$, based on the standard deviation of measured temperature deviations from the sinusoidal function during the melting season (MaySeptember). This figure shows that the variation of the summer and winter balance with elevation is in general well explained.

Figure 4 shows scatter diagrams of the measured and computed mass balance of Nigardsbreen similar to Figure 2 for Sátujökull. The quality of the model prediction of the summer balance at the individual elevations in Figure 4a (model explains $94 \%$ of variance) is similar to that for Sátujökull and the predicted winter balance (model explains $67 \%$ of variance) is better than for Sátujökull. The elevation-averaged values in Figure $4 \mathrm{~b}$ show that the model is able to explain year-to-year summer-balance variations on the basis of year-to-year temperature and precipitation fluctuations reasonably well (the model explains $62 \%$ of variance) but year-to-year winterbalance variations are not so well predicted the model explains $48 \%$ of variance).

\section{Qamanârssûp sermia, West Greenland}

The mass-balance data from Qamanârssûp sermia are from 14 "centre-line" stakes from the mass-balance years 197980 to $1986-87$ and span the elevation range 110 $1410 \mathrm{~m}$ a.s.l. Missing mass-balance data are estimated by a statistical procedure using data from the other stakes (personal communication from R.J. Braithwaite). The mass-balance year extends from 1 September to 31 August. The model computations are based on monthly temperature averages computed from temperature measurements at Qamanârssûp sermia Base Camp $\left(64^{\circ} 29^{\prime} \mathrm{N}\right.$,

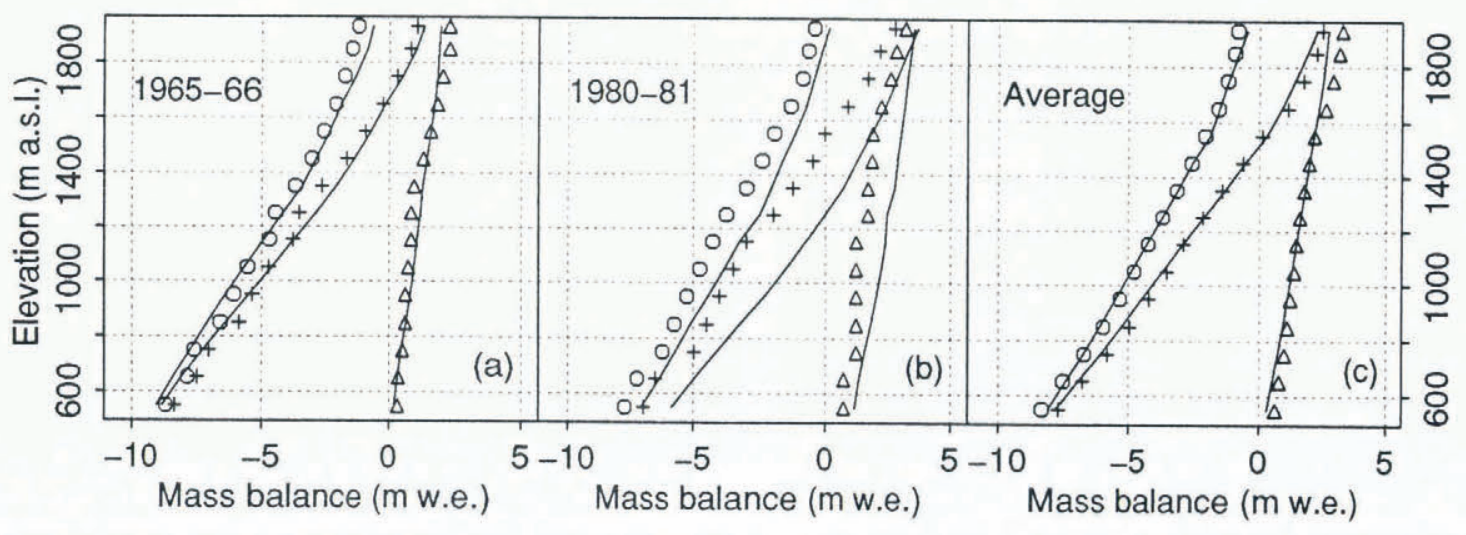

Fig. 3. Measured (symbols) and compuled (solid curves) mass balance (winter $(\triangle)$, summer $(\bigcirc)$ and year $(+))$ at Nigardsbreen for the mass-balance years 196566 and 1980-81 and for the average of the years $1964-65$ to 198081 and 1983-84 to 1989-90. Model parameters are the same for all the years (cf. Tables 3 and 4). 

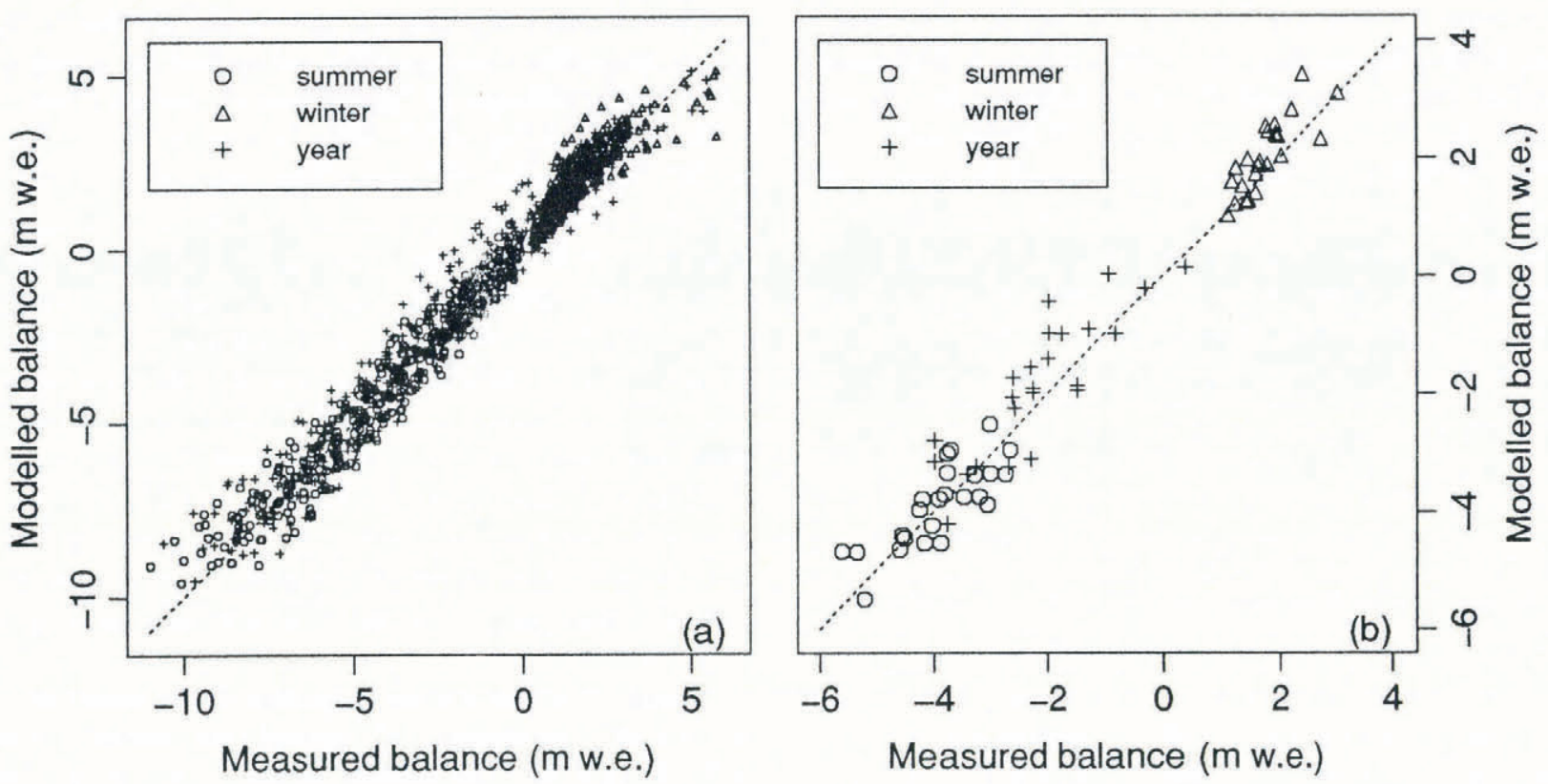

Fig. 4. Measured and computed mass balance of. Nigardsbreen for the mass-balance years 1964-6.5 to 1980-81 and $1983-$ 84 to 1989-90. (a) Winter $(\triangle)$, summer $(\mathrm{O})$ and yearly $(+)$ mass balance of individual years at each elevation. (b) Elevation-averaged values for each year.

$49^{\circ} 29^{\prime}$ W, $760 \mathrm{~m}$ a.s.l.). Missing temperature values are estimated from temperatures at Nuuk/Godthåb, about $150 \mathrm{~km}$ away from Qamanârssûp sermia Braithwaite and Olesen, 1993). The mass-balance and temperature measurements were carried out by the Geological Survey of Greenland (Gronlands geologiske undersogelse, GGU) Braithwaite and Olesen, 1989; Olesen and Braithwaite, 1989 ).

The mass-balance model is derived for temperate glaciers and ice caps. The Greenland ice sheet is, of course, not temperate. However, the mass-balance data from Qamanârssûp sermia come from the ablation area of the ice sheet, where internal accumulation is not particularly important due to the high net ablation.

The degree-day computations are based on monthly temperature averages assuming temperature deviations from the monthly mean are normally distributed with a standard deviation $\sigma$. The standard deviation of the temperature deviations was chosen as $\sigma=3.5^{\circ} \mathrm{C}$. The degree-day computations above for Sátujökull and Nigardsbreen were, however, based on daily temperature data. Jóhannesson and others (1993) showed that degree-day sums computed from daily temperature data with the MBT model are consistent with degree-day sums computed from monthly temperature data (cf. Braithwaite, 1984) and that the degree-day sums are not sensitive to the exact value of $\sigma$ used.

Accumulation or winter balance data at the stakes on Qamanârssûp sermia is not available. Winter-balance measurements for stakes at 1200 and $1410 \mathrm{ma.s.1.,}$ together with measured precipitation at Nuuk/Godthåb and measured summer precipitation at the Qamanârssûp sermia base camp, indicate that the yearly precipitation on the glacier is between 0.5 and $1.0 \mathrm{~m}$ w.e., with little gradient with elevation. A fixed value of $0.7 \mathrm{~m}$ w.e. for the yearly precipitation with uniform distribution between the months of the year is used in the model computations.
Other values of the precipitation did not significantly affect the calibrated values of the temperature gradient and the degree-day fáctor for ice. Varying the precipitation from year to year, based on variation in the measured precipitation at Nuuk/Godthåb, turned out to have little effect on the model calibration. Wind correction for snow or rain is not used and zero precipitation gradient with elevation is specified. The fixed model parameters for Qamanârssûp sermia are given in Table 5 .

The mass-balance measurements (Fig. 5) exhibit considerable local deviations from a smooth variation with elevation, mainly due to systematic spatial variations

Table 5. Fixed-model parameters for Qamanârssûp sermia

Parameter Name Value Unit

Standard deviation of

temperature deviations

Snow/rain threshold

Precipitation/elevation gradient

Rain correction factor

Snow correction factor

Precipitation correction factor

Snow thickness used in

degree-day computations

Refreezing ratio

Elevation of temperature station

Elevation of precipitation station

Starting elevation for

precipitation gradient

$\begin{array}{lll}\text { sgm } & 3.5 & { }^{\circ} \mathrm{C} \\ \text { tsn } & 1.0 & { }^{\circ} \mathrm{C} \\ \text { grp } & 0.0 & 1 \text { per } \\ & & 100 \mathrm{~m} \\ \text { rko } & \dagger & 1 \\ \text { sko } & \dagger & 1 \\ \text { pko } & \dagger & 1 \\ \text { sis } & 0.3 & \mathrm{~m} \text { w.e. } \\ & & \\ \text { rfr } & 0.07 & 1 \\ \text { elt } & 760 & \text { m a.s.l. } \\ \text { elp } & \dagger & \text { ma.s.l. } \\ \text { elq } & \dagger & \text { ma.s.l. }\end{array}$

$\doteqdot$ not used. 


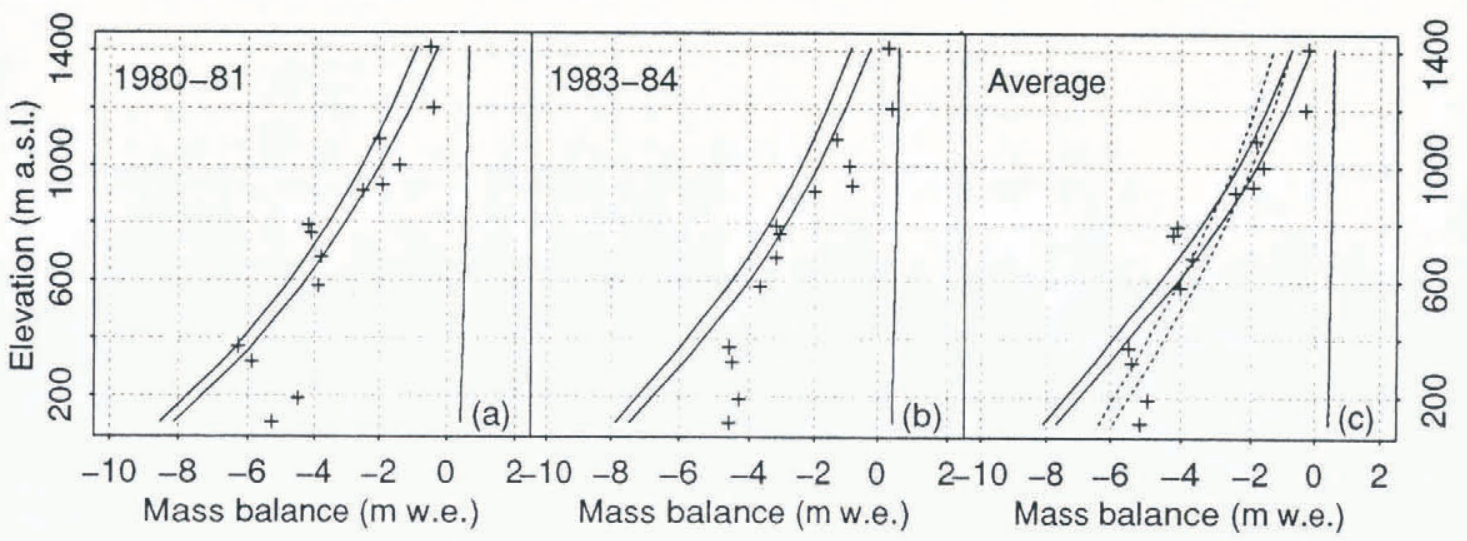

Fig. 5. Measured yearly mass balance (+) and computed yearly accumulation, mass balance and ablation (solid and dashed curves) at Qamanârssuip sermia for the mass-balance years 1980-81 and 1983-84 and for the average of the years 197980 to 1986 87. Model parameters are the same for all the years ( $c f$. Tables 5 and 6 ). The solid curves correspond to the parameter set in Table 6 derived from mass-balance data in the elevation range $370-1410 \mathrm{~m}$ a.s.l. The dashed curves correspond to the best-fit parameter set when points below 370 m a.s.l. are included.

in the accumulation over the ice sheet which can in some cases be explained by the local glacier landscape (personal communication from R.J. Braithwaite). Below about $370 \mathrm{~m}$ a.s.l., the measurements show zero or even slightly negative mass-balance gradient with elevation over an elevation range of about $300 \mathrm{~m}$ which may to some extent be caused by local advection of cold air from areas adjacent to the lower parts of the glacier (personal communication from R.J. Braithwaite). This feature of the mass-balance profile cannot be adequately modelled by linear precipitation and temperature gradients. Including the mass-balance measurements below $370 \mathrm{~m}$ a.s.l. in the model calibration leads to a set of unrealistic model parameters which greatly underestimate the massbalance gradient above $370 \mathrm{~m}$ a.s.l. (Jóhannesson, 1993). Since the overall shape of the mass-balance profile above $370 \mathrm{ma}$ a.s.l. is characterized by a relatively monotonic increase of the net balance with elevation (cf. Fig. 5), the calibration procedure was performed for data in the elevation range $370-1410 \mathrm{ma}$ a.s.l. The results of this calibration are given in Table 6 .

These parameter values explain $84 \%$ of the variance in the measured yearly net balance at the individual elevations above $370 \mathrm{~m}$ a.s.l. The parameter values in Table 6 are in fairly good agreement with the average degree-day factors estimated by Braithwaite and Olesen

Table 6. Best-fit parameters determined from the measured yearly net balance in the elevation range $370-1410 \mathrm{~m}$ a.s.l. on Qamanârssûp sermia

\section{Parameler}

Name Value Unit

\begin{tabular}{|c|c|c|c|}
\hline Degree-day factor for ice & ddi & 0.0073 & m w.e. ${ }^{\circ} \mathrm{C}^{-1} \mathrm{~d}^{-1}$ \\
\hline Degree-day factor for snow & dds & 0.0028 & mw.e. ${ }^{\circ} \mathrm{C}^{-1} \mathrm{~d}^{-1}$ \\
\hline Temperature lapse rate & grt & 0.66 & ${ }^{\circ} \mathrm{C}$ per $100 \mathrm{~m}$ \\
\hline Residual variance & $\sigma_{\delta}^{2}$ & 0.5 & $\mathrm{~m}^{2}$ w.e. \\
\hline Residual standard error & $\sigma_{\delta}$ & 0.7 & mw.e. \\
\hline
\end{tabular}

(1989, 1993) from mass-balance measurements at stake 751 close to Base Camp, which are $0.0077 \mathrm{~m}$ w.e. ${ }^{\circ} \mathrm{C}^{-1} \mathrm{~d}^{-1}$ and $0.0079 \mathrm{mw}$.e. ${ }^{\circ} \mathrm{C}^{-1} \mathrm{~d}^{-1}$, respectively, for ice and $0.0025 \mathrm{~m}$ w.e. ${ }^{\circ} \mathrm{C}^{-1} \mathrm{~d}^{-1}$ for snow.

Figure $5 \mathrm{a}$ and $\mathrm{b}$ show the measured yearly mass balance and the computed yearly accumulation, ablation and mass balance for two of the eight mass-balance years using the parameters given in Tables 5 and 6 . The model results for 1980-81 (Fig. 5a) are the best for 8 years and the model results for 198384 (Fig. 5b) are the worst. Figure 5c shows the average of the mass-balance measurements for the eight mass-balance years, together with the computed yearly accum-ulation, ablation and mass balance based on the average monthly temperature and precipitation for the same years. (Figure $5 \mathrm{c}$ also shows the model results corresponding to best-fit model parameters when data below $370 \mathrm{~m}$ a.s.l are included.)

Figure 6 shows scatter diagrams of the measured and computed yearly mass balance of Qamanârssûp sermia similar to Figures 2 and 4 for Sátujökull and Nigardsbreen, respectively. The quality of the model prediction of the yearly balance in Figure 6a the model explains $84 \%$ of variance) is slightly worse than shown in Figures 2a and $4 \mathrm{a}$ for the summer balance or yearly balance of Sátujökull and Nigardsbreen, respectively. The elevationaveraged values in Figure $6 \mathrm{~b}$ show that the model is able to explain year-to-year variations in the mass balance on the basis of year-to-year temperature fluctuations reasonably well (the model explains $69 \%$ of variance).

\section{PARAMETER STABILITY}

An important question with regard to modelling of climate changes is whether model parameters determined from the current climate can be used to predict changes associated with a different climate. The glacier mass-balance model used here reproduces large variations in the mass balance with elevation and from year to year using the same parameter set. The temperature change over the altitude range of the glaciers is much greater than the expected $\mathrm{CO}_{2}$-induced temperature change 

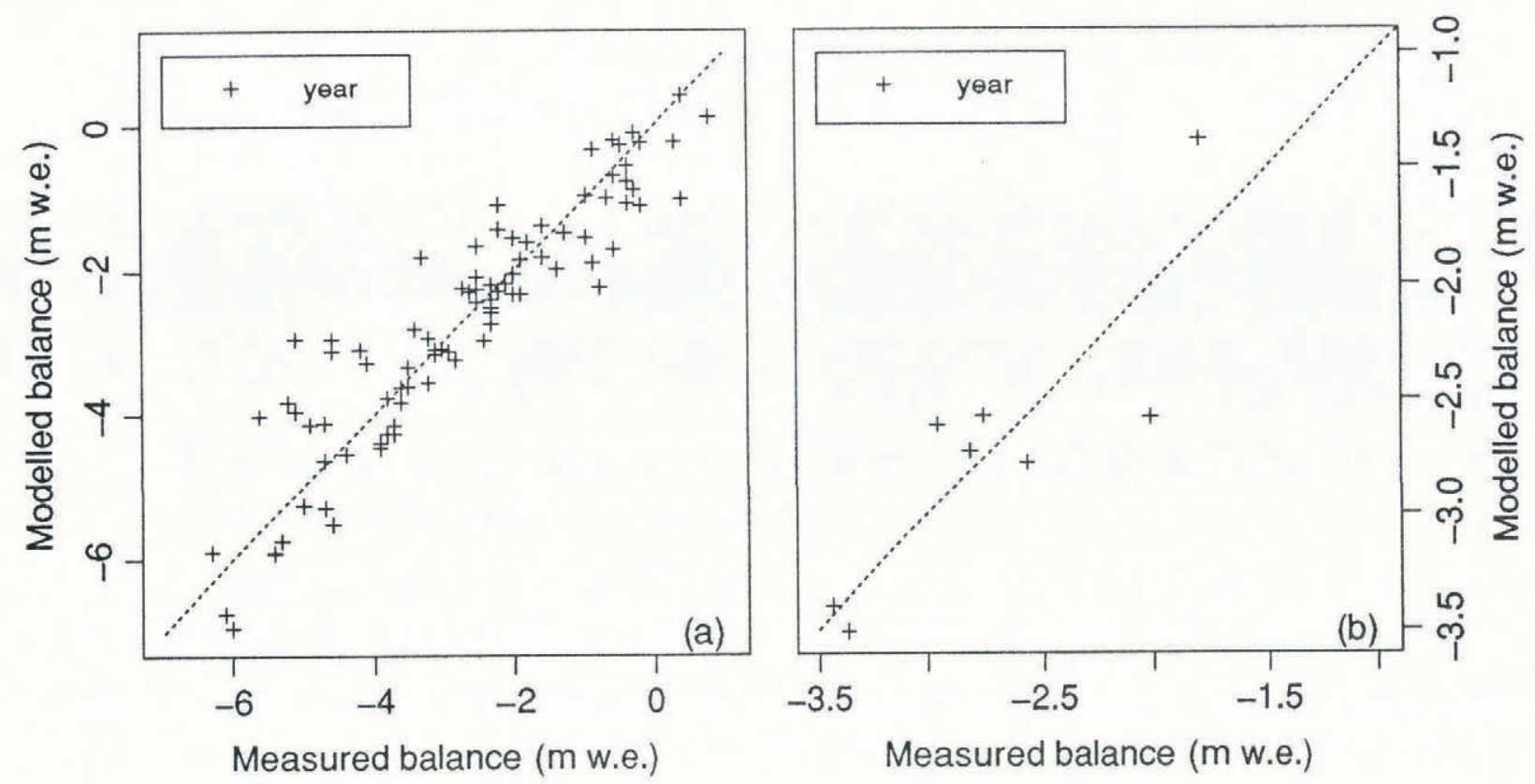

Fïg. 6. Measured and computed yearly mass balance of Qamanârssûp sermia above 370 ma.s.l. for the mass-balance years $1979-80$ to 1986-87. (a) Yearly mass balance (+) of individual years at each elevation. (b) Elevation-averaged values for each year.

during the next century, and year-to-year variations in the temperature are of a magnitude similar to the expected climatic warming during the next 50-100 years. Furthermore, degree-day factors for ice determined from measurements in Iceland, Norway and Greenland show relatively little spreading across a wide range of different climatic regimes. A possible climatically induced change in the degree-day factors may therefore be expected to have only a small effect on the ablation compared to the large change in the ablation caused directly by the temperature change.

Another related question is whether degree-day models are suitable for estimating mass-balance changes due to climatic warming at all, because they relate all snow and ice melting to temperature through the degreeday sum. The largest energy-balance component, however, is typically net radiation, which is often not well correlated with temperature. Thus, if the ablation is modelled as linearly dependent on the degree-day sum, one may expect the model to predict too high sensitivity to temperature changes, because in reality only a part of the energy available for melting is directly related to temperature. However, experience shows that ablation and temperature (or rather the degree-day sum) are well correlated, whereas there is a rather poor correlation between ablation and net radiation (Braithwaite, 1981). This question may be addressed on the basis of Figures $2 \mathrm{~b}, 4 \mathrm{~b}$ and $6 \mathrm{~b}$ which show that the model reproduces 60 $80 \%$ of the measured year-to-year variance in the elevation-averaged summer balance or net balance. In addition, the slope through the summer-balance or netbalance points in the figures is close to 1 , which indicates that sensitivity of the model to temperature variations is not in fact too high. If the sensitivity of the model had been significantly overestimated, then the summerbalance and net-balance points in Figures $2 \mathrm{~b}, 4 \mathrm{~b}$ and $6 \mathrm{~b}$ would have had a trend with a slope greater than 1 .
The question of model-parameter stability can be studied in some detail for Nigardsbreen, because the measurements there cover a long time period which can be divided into sub-sets with significantly different temperature and precipitation. In order to study the stability of the degree-day factors and the temperature gradient found by non-linear minimization, the calibration was performed for the 12 first years and the 12 last years separately. The results are shown in Table 7 .

The value of the degree-day factor for ice is evidently quite stable (cf. Table 4 ). The variations in the degreeday factor for snow and the temperature gradient are greater. The reason for this difference is that there is a strong correlation $(r=0.94)$ between the parameters dds and grt both for Nigardsbreen and for Sátujökull (cf. Johannesson and others, 1993). As a consequence of the high correlation between dds and grt, data errors and simplifying assumptions in the model will lead to greater uncertainty in the estimates of the degree-day factor for snow and in the temperature gradient than in the degreeday factor for ice.

The effect of temperature on the estimated parameter values was further investigated by sorting the massbalance years according to the average temperature of each year. The model parameters were then estimated for the 12 coldest and the 12 warmest years separately. The results are shown in Table 8 .

Again, variations in the degree-day factor for snow are greater than variations in the degree-day factor for ice ( $\mathrm{cf}$. Table 7). There is no significant reduction in the estimated degree-day factors with temperature which would be expected if the sensitivity of glacier mass balance to temperature was highly overestimated by degree-day mass-balance models. The changes in the parameter values could theoretically arise from random mass-balance fluctuations with variance similar to the variance of the residuals in Tables 7 and 8 (i.e. the 
Table 7. Best-fit degree-day factors and temperature gradient for Nigardsbreen determined for two 12 year periods. $T_{\mathrm{av}}$ is the average temperature of the mass-balance years in each period at Bjorkehaug

\begin{tabular}{|c|c|c|c|c|c|c|}
\hline Name & $d d i$ & $d d s$ & $g r l$ & $\sigma^{2}$ & $\sigma$ & $T_{\mathrm{av}}$ \\
\hline Unit & mw.e. ${ }^{\circ} \mathrm{C}^{-1} \mathrm{~d}^{-1}$ & mw.e. ${ }^{\circ} \mathrm{C}^{-1} \mathrm{~d}^{-1}$ & ${ }^{\circ} \mathrm{C}$ per $100 \mathrm{~m}$ & $\mathrm{~m}^{2}$ w.e. & m w.e. & ${ }^{\circ} \mathrm{C}$ \\
\hline First 12 years & 0.0065 & 0.0048 & 0.62 & 0.30 & 0.55 & 3.8 \\
\hline Last 12 years & 0.0064 & 0.0040 & 0.55 & 0.44 & 0.66 & 3.6 \\
\hline Combined & & & & 0.37 & 0.61 & 3.7 \\
\hline
\end{tabular}

changes in the parameter values are consistent with the computed standard error of the parameter estimates).

The variance of the residuals corresponding to all 24 years is reduced from $0.39 \mathrm{~m}^{2}$ w.e. (cf. Table 4) to 0.37 $\mathrm{m}^{2}$ w.e. by using separate parameters for two 12 year periods (cf. Table 7 ) and to $0.36 \mathrm{~m}^{2}$ w.e. by using separate parameters for the 12 coldest and 12 warmest years (cf. Table 8 ). This is a relatively small reduction in the variance for an effective doubling in the number of free model parameters, and supports our assertion that model parameters are stable over the temperature variations of these 24 years. Similar results have been obtained when mass-balance years were divided into four groups of 6 years sorted according to the average temperature of each year (Jóhannesson and others, 1993).

The temperature differences considered above $1.1^{\circ} \mathrm{C}$ difference between 12 coldest/warmest years, $1.8^{\circ} \mathrm{C}$ difference between six coldest/warmest years) are of a similar magnitude to the climatic warming which is considered in the following section $\left(2{ }^{\circ} \mathrm{C}\right)$. We assume therefore these parameters will not change significantly for the climate scenarios considered here.

\section{CLIMATE GHANGES AND GLACIER MASS BALANCE}

For the North Atlantic area, the climate scenarios which are used in the project "Climate change and energy production" specify a warming rate of $0.25^{\circ} \mathrm{C}$ per decade in mid-summer and $0.35 \mathrm{C}$ per decade in mid-winter with a sinusoidal variation through the year. Precipitation is predicted to increase by $5 \%$ per degree of warming. The effect of a warmer climate on glacier mass balance is briefly analyzed here by computing the mass balance of the three glaciers for a temperature increase of $2 \mathrm{C}$, with and without an accompanying $10 \%$ precipitation increase. This is similar to the average warming that may occur over a time period of approximately 70 years according to the scenario.

Figure 7 shows the average mass balance of Sátujökull, Nigardsbreen and Qamanârssûp sermia (solid curves, cf. Figures 1, 3 and 5), together with the mass balance predicted for $2{ }^{\circ} \mathrm{C}$ warmer climate with the same precipitation and for $2{ }^{\circ} \mathrm{C}$ warmer climate with $10 \%$ more precipitation. This figure shows that the accumulation of Qamanârssûp sermia is rather insensitive to the climate change but the predicted winter balance of Sátujökull and Nigardsbreen at the lower elevations is reduced even when the precipitation is increased by $10 \%$, because a larger fraction of the precipitation falls as rain in a warmer climate. The summer balance yearly ablation for Qamanârssûp sermia) and the net balance of all glaciers are predicted to decrease (become more negative) by between 2.4 and $2.9 \mathrm{mw}$.e. year ${ }^{-1}$ at the lowest elevations, and by between 1.1 and $1.3 \mathrm{mw}$.e. year $^{-1}$ at the highest elevations. A warming of $2{ }^{\circ} \mathrm{C}$ is predicted to lead to a $220 \mathrm{~m}$ or $180 \mathrm{~m}$ rise in the equilibrium-line altitude of Sátujökull, for no precipitation change or $10 \%$ precipitation increase, respectively. The corresponding rise in the equilibrium-line altitude for Nigardsbreen is $280 \mathrm{~m}$ or $230 \mathrm{~m}$, respectively. All the points on Qamanârssûp sermia which are considered here are below the equilibrium line and the rise in the equilibrium-line altitude is therefore not determined for Qamanârssûp sermia.

At an elevation of $790 \mathrm{~m}$ a.s.1., the yearly ablation at Qamanârssûp sermia is predicted to increase by $1.9 \mathrm{~m}$ w.e. This is in good agreement with the previous results of Braithwaite and Olesen (1993) who predicted that the

Table 8. Best-fit degree-day factors and temperature gradient for Nigardsbreen determined for the 12 coldest and the 12 warmest mass-balance years

\begin{tabular}{|c|c|c|c|c|c|c|}
\hline Name & $d d i$ & $d d s$ & $g r t$ & $\sigma^{2}$ & $\sigma$ & $T_{\mathrm{av}}$ \\
\hline Unit & m w.e. ${ }^{-1} \mathrm{C}^{-1}$ & mw.e. ${ }^{C}{ }^{-1} d^{-1}$ & ${ }^{\circ} \mathrm{C}$ per $100 \mathrm{~m}$ & $\mathrm{~m}^{2}$ w.e. & mw.e. & ${ }^{\circ} \mathrm{C}$ \\
\hline 12 coldest years & 0.0064 & 0.0050 & 0.59 & 0.31 & 0.56 & 3.2 \\
\hline 12 warmest years & 0.0065 & 0.0042 & 0.59 & 0.41 & 0.64 & 4.3 \\
\hline Combined & & & & 0.36 & 0.60 & 3.7 \\
\hline
\end{tabular}



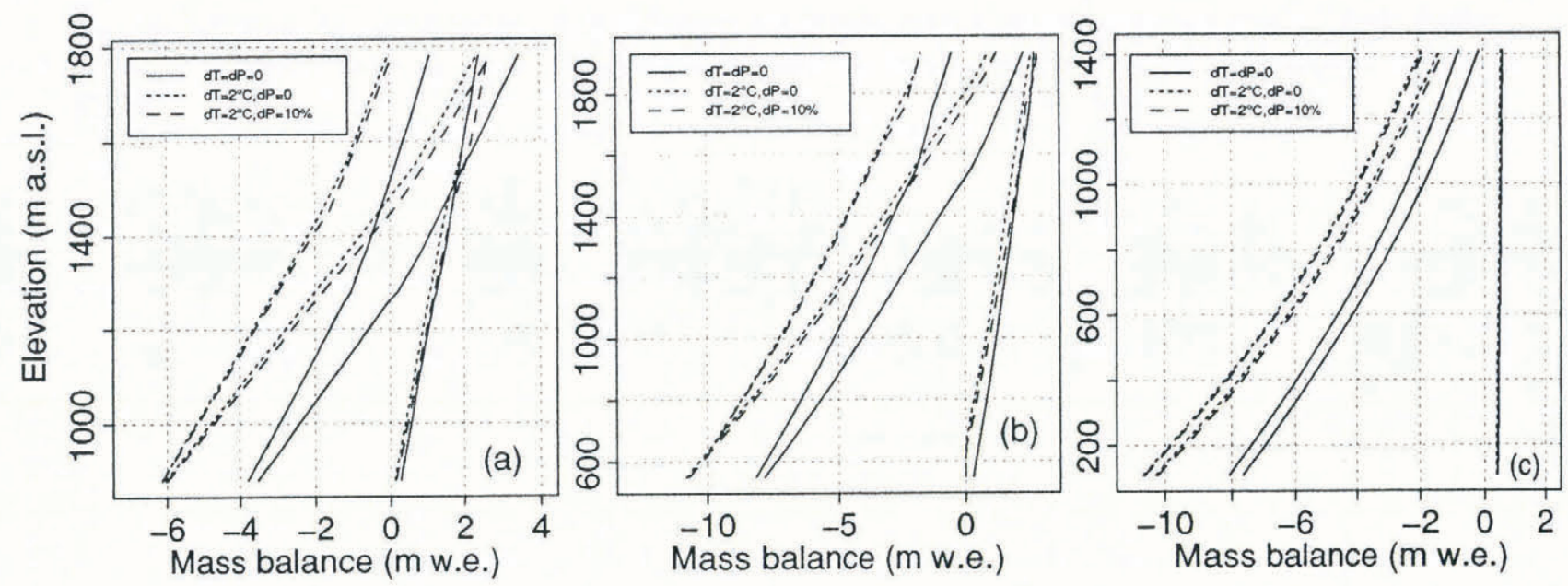

\begin{abstract}
Fig. 7. Modelled winter, summer and net balance of Sátujökull (a) and Nigardsbreen (b) and modelled yearly accumulation, ablation and mass balance of Qamanârssûp sermia $(c)$ under the present climate (solid curves) and a warmer climate (dashed curves). For each set of three curves of the same line type, the lefthand curve is the summer balance (yearly ablation for Qamanârssup sermia), the middle curve is the net balance and the righthand curve is the winter balance (yearly accumulation for Qamanârssûp sermia). The curves for the present climate are identical to the curves labelled "Average" in Figures 1, 3 and 5. Model parameters are given in Tables $1-6$.
\end{abstract}

yearly ablation at stake 751 at $790 \mathrm{~m}$ a.s.l. is increased by about $1 \mathrm{mw}$.e. ${ }^{\circ} \mathrm{C}^{-1}$ of warming using a degree-day model. Braithwaite and Olesen (1990a) calculated a somewhat lower increase in the melting during the months June-August using an energy-balance model.

The above results were computed with a uniform distribution of the warming within the year. Moderately higher warming during the winter months according to the scenario described above gives essentially the same results as uniform warming if the temperature increase during the summer is the same in both cases. Recent coupled GCM model computations (Manabe and others, 1992 ) indicate that there is little seasonal difference in the warming in the North Atlantic area, but winter warming over the Arctic Ocean and north Greenland is predicted to be much higher than warming during the summer. Boggild and others (1994) showed that the large seasonal difference in the warming, which is predicted for north Greenland, may lead to a significant increase in snow accumulation which may partly compensate for the effect of increased ablation on the net balance of the ice sheet.

\section{GLIMATE CHANGES AND GLACIER RUN-OFF}

It is possible to estimate the hydrological consequences of changes in glacier mass balance due to climate change from the mass-balance computations which are described in the previous section. Figure 8 shows glacier run-off at three elevations from Sátujökull (a) and Nigardsbreen (b) for the present climate, together with the computed runoff for $2{ }^{\circ} \mathrm{C}$ warmer climate with the same precipitation and for $2^{\circ} \mathrm{C}$ warmer climate with $10 \%$ more precipitation. The results are obtained by integrating the model for the calendar months starting on 1 October for Sátujökull and for 30 or $31 \mathrm{~d}$ periods starting on 10 September for Nigardsbreen. Figure $8 \mathrm{a}$ and $\mathrm{b}$ shows the total run-off as a function of time and Figure $8 \mathrm{c}$ and $\mathrm{d}$ shows the computed increase in run-off due to the warming. The curves for Sátujökull (Fig. 8a) are difficult to distinguish from each other because the run-off curves at 1400 and $1800 \mathrm{~m}$ a.s.l. for the warmer climates almost coincide with the run-off curves at 1000 and $1400 \mathrm{~m}$ a.s.l. for the present climate.

Figure 8 shows that the run-off during the ablation season increases by $50-1501 \mathrm{~s}^{-1} \mathrm{~km}^{-2}$ for Sátujökull and by $50-200 \mathrm{l} \mathrm{s}^{-1} \mathrm{~km}^{-2}$ for Nigardsbreen. As expected, the change is greater at the lower elevations. The onset of glacier run-off is about 1 month earlier and the ablation season is about 2 months longer in the warmer climates than under present climatic conditions. The $10 \%$ precipitation increase has only a marginal effect on run-off.

\section{DISCUSSION AND CONGLUSIONS}

The degree-day mass-balance model described above works well for three glaciers in significantly different climate regimes. With the long time series of mass-balance data from Nigardsbreen, it was shown that the model parameters are relatively stable in time, and that climate changes within the measurement period do not lead to a significant modification of the parameters. This indicates that the model is suitable for a study of the effect of climate changes on glacier mass balance. The model explains over $80 \%$ of the variance in measured summer or yearly net balance at the individual elevations on the glaciers and it furthermore explains between $60 \%$ and $80 \%$ of the measured year-to-year variance in the yearly summer or net balance averaged over all the elevations on each glacier. Model performance is worse for winter balance, particularly for Sátujökull where the model explains only $42 \%$ of the variance. It can be seen in Figure 1 that the winter-balance curves are not well modelled using a linear precipitation gradient but that the form of the curves is reasonably constant from year to year. Thus, prediction of winter balance could probably be improved using an alternative (non-linear) precipit- 

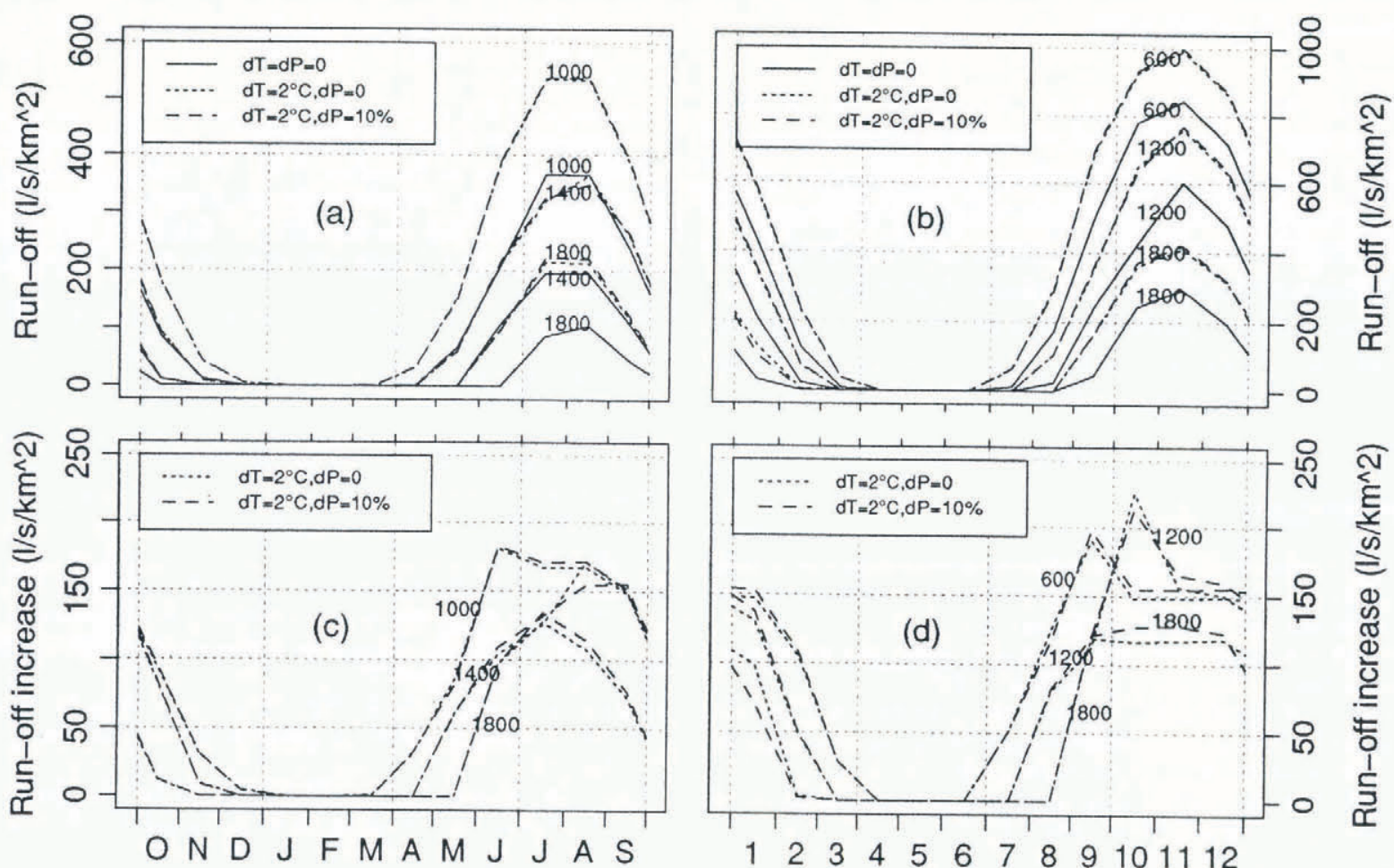

\begin{abstract}
Fig. 8. Glacier run-off as a function of time from the beginning of the mass-balance year for Sátujökull (a) and Nigardsbreen (b). The time axis for Sátujökull is labelled with the months, but the time axis for Nigardsbreen is labelled with the number of 3031 d periods starting on 10 September. Solid curves are for the present climate, short-dashed curves are for a $2 \mathrm{C}$ warmer climate with the same precipitation and long-dashed curves are for a $2{ }^{\circ} \mathrm{C}$ warmer climate with $10^{\circ}$ more precipitation. (c) and (d) show the increase in run-off due to the warmer climates. Results from three elevations are plotted for each glacier. The curves are labelled with the elevations in $m$ a.s.l. The results, with and without the precipitation increase, are often so close that the shorl- and long-dashed curves cannot be distinguished.
\end{abstract}

ation distribution with elevation. This pattern could be defined by elevation-dependent correction factors determined by least-squares fitting as described by Boggild and others (1994).

The degree-day factors found here are in relatively good agreement with parameter values which have previously been used for hydrological and glaciological models in Iceland, Norway and Greenland. The degreeday factors for ice for Sátujökull and Qamanârssûp sermia are higher than for Nigardsbreen, which may be partly explained by the windiness of the climate in Iceland and Greenland. High wind speeds tend to increase sensible-heat flux from the air to the glacier surface. The calibration indicates a temperature lapse rate between $0.5^{\circ}$ and $0.7^{\circ} \mathrm{C}$ per $100 \mathrm{~m}$ for the glaciers. This is close to the saturated adiabatic lapse rate near the surface of the Earth at temperatures near $0^{\circ} \mathrm{C}$ and similar to values which are most often used in hydrological

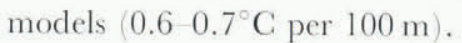

Model calibration is perhaps the most critical part of hydrological and glaciological modelling studies. If the models are too unconstrained, it may be possible to fit the measurements quite well for a wide range of model parameters, resulting possibly in an unrealistic model response to changes in input data. It is therefore important to make maximum use of available measurements to constrain the model parameters as much as possible. This is the reason that the model calibration performed here is based on yearly mass-balance data instead of an average over the measurement period. The year-to-year variations in the measurements constrain the model parameters and the degree to which the model reproduces these variations is a check of the validity of the calibration.

Calibration of degree-day glacier mass-balance models is somewhat different from calibration of traditional hydrological degree-day snowmelt models which are calibrated using river discharge measurements. Glacier mass-balance measurements have very coarse time resolution, with typically only two measurements per year at each altitude. However, glacier mass-balance measurements tend to have a good altitude coverage, often covering the entire altitude range of the glacier. Glacier mass-balance models are therefore suitable for estimating the variation of the run-off with elevation, but less suitable for estimating the time-dependence of the melting. River-discharge measurements, on the other hand, usually have good time resolution but poor altitude and spatial coverage. Therefore, hydrological models are suitable for analyzing time-dependent processes which affect the melting, i.e. storage of liquid water in the snowpack, the effect of ageing of the snow on albedo, refreezing of meltwater, etc., but they are not particularly suitable for analyzing altitude-dependence of parameters. Combined mass-balance/run-off models calibrated using massbalance data and high-resolution discharge data can lead to improved estimates of model parameters, together with estimates of their time-dependence. 


\section{ACKNOWLEDGEMENTS}

This study was carried out as a part of the project "Climate change and energy production", a joint project between Norway, Sweden, Finland, Denmark and Iceland sponsored by the Nordic Council of Ministers. Meteorological data were provided by the Icelandic, Norwegian and Danish meteorological institutes. Massbalance data from Qamanârssûp sermia were provided by R. Braithwaite (GGU), who also gave useful advice during the course of this study.

\section{REFERENCES}

Bergström, S. 1976. Development and application of a conceptual runoff model for Scandinavian catchments. Lund, Lund University. Department of Water Resources Engineering. Bulletin, Ser. A 52.

Bergström, S. and 7 others. 1992. Snow modeling, water resources, climate change. Report STF60 A92023, SINTEF NHL.

Boggild, C. E., N. Reeh and H. Oerter. 1994. Modelling ablation and mass-balance sensitivity to climate change of Storstrommen, northeast Greenland. Global and Planetary Change, 9 1-2), 79-90.

Braithwaite, R.J. 1981. On glacier energy balance, ablation, and air temperature. J. Glaciol., 27 97), 381-391.

Braithwaite, R.J. 1985. Calculation of degree-days for glacier-climate research. Z. Gletscherkd. Glazialgeol., 20, 1984, 1-8.

Braithwaite, R.J. 1992. Degree-day factor, energy balance, and the increased melting of the Greenland ice sheet under a warmer climate. Gronlands Geologiske Undersogelse. Rapport 155, 79-83.

Braithwaite, R.J. and O.B. Olesen. 1985. Ice ablation in West Greenland in relation to air temperature and global radiation. Z. Gletscherkd. Glazialgeol., 20, 1984, 155-168.

Braithwaite, R. J. and O. B. Olesen. 1989. Calculation of glacier ablation from air temperature, West Greenland. In Oerlemans, J., ed. Glacier fluctuations and climate change. Dordrecht, Kluwer Academic Publishers, $219-233$.

Braithwaite, R.J. and O.B. Olesen. 1990a. Increased ablation at the margin of the Greenland ice sheet under a greenhouse-effect climate. Ann. Glaciol., 14, 20-22.

Braithwaite, R.J. and O. B. Olesen. 1990b. A simple energy-balance model to calculate ice ablation at the margin of the Greenland ice sheet. J. Glaciol., 36(123), 222-228.

Braithwaite, R.J. and O.B. Olesen. 1993. Seasonal variation of ice ablation at the margin of the Greenland ice sheet and its sensitivity to climate change, Qamanârssûp sermia, West Greenland. J. Glaciol. 39 (132), 267-274.

Chambers, J. M. and T.J. Hastie. 1992. Statistical models in S. Pacific Grove, CA, Wadsworth \& Brooks/Cole Advanced Books \& Software.

Einarsson, K. and T. Jóhannesson. 1994. Correction of calibration biases in a runoff model for a partly glaciated river basin by the application of a glacier mass balance model. In Kern-Hansen, C., D. Rosbjerg and R. Thomsen, eds. Norsk Hydrologisk Konferens 1994 (NHK-94). Copenhagen, Nordisk Hydrologisk Program, 589-595. (NHPrapport 34 .)
Furmyr, S. and A. Tollan. 1975. Resultater og erfaringer av undersokelser i Filefjell representative omrâde 1967-1974. Oslo, Den Norske IHD-komité. Sekretariatet.

Gottlieb, L. 1980. Development and application of a runoff model for snowcovered and glacierized basins. Nord. Hydrol., 11 (5), 255-272.

Hólm, S. L. and K. Einarsson. 1992. The adaptation of the NAM2 runoff model to Icelandic conditions. Vannet $i$. Norden, 25 2), 3-7.

Houghton, J. T., G.J. Jenkins and J.J. Ephraums, eds. 1990. Climate change. The IPCC scientific assessment. Cambridge, Cambridge University Press.

Houghton, J. T., B. A. Callander and S. K. Varney, eds. 1992. Climate change 1992 - the supplementary report to the IPCC scientific assessment. Cambridge, Cambridge University Press.

Jóhannesson. T. 1993. Application of a degree-day mass balance model to the Qamanârssûp sermia oullet glacier, Wesl Greenland. Reykjavik, Orkustofnun. Report OS-93078/VOD-14B.

Jóhannesson, T. and T. Laumann. 1993. A review of degree-day glacier mass balance models in the Nordic countries. Vannet $i$. Norden, $26(1)$ $28-34$.

Jóhannesson. T., O. Sigurdsson, T. Laumann and M. Kennett. 1993. Degree-day glacier mass balance modelling with applications to glaciers in Iceland and Norway. Reykjavík, Orkustofnun. (Nordic Hydrological Programme. Rapport 33.

Laumann, T. and N. Reeh. 1993. Sensitivity to climate change of the mass balance of glaciers in southern Norway. \%. Glaciol., 39 (133), 656-665.

Manabe, S., M.J. Spelman and R. J. Stouffer. 1992. Transient responses of a coupled ocean -atmosphere model to gradual changes of atmospheric $\mathrm{CO}_{2}$. Part II: Seasonal response. J. Climate, 5 2), 105- 126.

Norges Vassdrags-og Elektrisitetsvesen (NVE). 1964-91. Glasio-hydrologiske undersokelser $i$. Norge. Oslo, Norges Vassdrags-og Elektrisitetsvesen. Vassdragsdirektoratet. NVE Publikasjon.

Oerlemans, J. 1992. Climate sensitivity of glaciers in southern Norway: application of an energy-balance model to Nigardsbreen, Hellstugubreen and Alfotbreen. J. Glaciol., 38(129), 223-232.

Olesen, O.B. and R.J. Braithwaite. 1989. Field stations for glacier climate research, West Greenland. In Ocrlemans, J., ed. Glacier fluctuations and climatic change. Dordrecht, Kluwer Academic Publishers, 207-218.

Ostrem, G. and M. M. Brugman. 1991. Glacier-mass balance measurements. A manual for field work. A guide for personnel with limiled backgrounds in glaciology. Third edition. Saskatoon, Environment Canada. National Hydrology Research Institute. (NHRI Science Report 4. )

Reeh, N. 1991. Parameterization of melt rate and surface temperature on the Greenland ice sheet. Polarforschung, 59 3), 1989, 113-128.

Sælthun, N. R. 1990. Forbedringer av de hydrologiske rutinene i HBV-modellen. Oslo, Norges Vassdrags-og Elektrisitetsvesen. Vassdragsdirektoratet. (VHD-notat 9/90.)

Salthun, N. R. 1992. Klimaendringer og energiproduksjon -en orientering. Vannet $i$ Norden, $25(2), 8-12$.

Sigurdsson, O. 1989. Afkoma Hofsjökuls 1987-1988. Reykjavík, Orkustofnun. (Report OS-89005/VOD-02B.)

Siguròsson, O. 1990. Vandamál við úrkomumælingar á Íslandi. In Sigbjarnarson, G., ed. Vatnid og landid, Vatnafradirádstefna, október 1987. Reykjavík, Orkustofnun, 101-110.

Sigurdsson, O. 1991. Afkoma Hofsjökuls 1988-1989. Reykjavík, Orkustofnun. Report OS-91052/VOD-08B.

Sigurdsson, O. 1993. Afkoma nokkurra jökla á Íslandi 1989-1992. Reykjavík. Orkustofnun. (Report OS-93032/VOD-02.) 